\title{
Interaction effects of N:P ratios and frequency of nutrient supply on the plankton community in the northern Baltic Sea
}

\author{
Annika Lagus ${ }^{1,{ }^{*}}$, Janne Suomela ${ }^{2}$, Harri Helminen ${ }^{2}$, Jaana M. Lehtimäki ${ }^{3}$, \\ Jaana Sipura ${ }^{1}$, Kaarina Sivonen ${ }^{3}$, Lassi Suominen ${ }^{1}$ \\ ${ }^{1}$ Section of Ecology, Department of Biology, University of Turku, 20014 Turku, Finland \\ ${ }^{2}$ Southwest Finland Regional Environment Centre, PO Box 47, 20801 Turku, Finland \\ ${ }^{3}$ Department of Applied Chemistry and Microbiology, Division of Microbiology, PO Box 56, Viikki Biocenter, \\ 00014 Helsinki University, Finland
}

\begin{abstract}
An experiment was carried out in brackish seawater mesocosms to investigate the impacts of different N:P ratios and frequency of nutrient supply on phytoplankton and zooplankton communities in the Archipelago Sea, part of the northern Baltic Sea. The experiment used a $2 \times 2$ factorial design in which nitrogen $(\mathrm{N})$ and phosphorus $(\mathrm{P})$ were added in either an N-deficient or Redfield ratio either daily or at $1 \mathrm{wk}$ intervals. Both phytoplankton total biomass and the biomass of most phytoplankton groups increased most in the enrichments with a Redfield ratio. The effect of nutrient addition frequencies varied with time and between the 2 nutrient ratios. The biomass of heterocystous $\mathrm{N}_{2}$-fixing cyanobacteria was highest in the daily nutrient enrichment, while chlorophytes increased most in the weekly Redfield treatment. The concentration of cyanobacterian hepatotoxins increased during the experiment, but was not affected by the nutrient enrichments. The biomass of calanoid copepods increased more in the weekly than in the daily enrichments when the nutrients were supplied in a Redfield ratio. Small rotifers, on the other hand, were favored by the Redfield nutrient enrichment, especially when the nutrients were added daily. Based on the results of this study it seems that a daily nutrient supply favors cyanobacterial growth, while an intermittent but heavier nutrient discharge may result in a more advantageous plankton community, with fewer cyanobacteria and a zooplankton community dominated by larger species.
\end{abstract}

KEY WORDS: Phytoplankton - Cyanobacteria $\cdot$ Zooplankton $\cdot$ Nutrient pulsing $\cdot$ Nutrient ratio $\cdot$ Mesocosm · Factorial design · Baltic Sea

\section{INTRODUCTION}

The availability of nitrogen and phosphorus regulates primary production and plankton community structure in most aquatic ecosystems (Hecky \& Kilham 1988). The supply of these nutrients may be fairly continuous or occur in irregular pulses, and be spatially and temporally variable. Continuous nutrient enrichment often originates from a point source, such as a municipal sewage treatment plant, the discharge of which tends to vary little over time. Nutrient pulses, on the other hand, may be generated by land run-off, wind-generated mixing and upwelling (Kononen et al. 1996, Lapointe \& Matzie 1996), release from sediment (Pitkänen et al. 2001), mineralization of organic matter (Fenchel 1988) and, on a small scale, also by animal excretion (Vanni 2002). The effect of the supply of nitrogen and phosphorus on the plankton community depends not only on the total amount of the nutrients, but also on their proportions (Tilman et al. 1982, Sommer 1989, Lagus et al. 2004) and on the frequency of nutrient input (Turpin \& Harrison 1979, Sommer 1985, Svensen et al. 2002). 
Phytoplankton species selection based on competition for nutrients is dependent on species-specific differences in nutrient transport kinetics, assimilation, and storage capacity (Tilman et al. 1982, Sommer 1989). Sommer (1985) divided algae into 3 categories based on their ability to utilize nutrients: (1) affinity specialists - species that have low requirements for nutrients and are efficient users of low nutrient concentrations; (2) velocity specialists - species that have high uptake and growth rates and are able to utilize temporary nutrient enrichment for rapid growth; and (3) storage specialists - species that are capable of storing nutrients in intracellular pools and which usually have relatively high uptake rates but only moderate maximum growth rates. A low and continuous nutrient supply should select for affinity specialists, whereas a pulsed nutrient supply should favor both velocity specialists that are capable of rapid growth after nutrient pulses and storage specialists that are capable of luxury consumption (Sommer 1985, Grover 1991).

The nutrient kinetics of phytoplankton are strongly related to size (Stolte \& Riegman 1996). Small algal species, with a high cellular surface to volume ratio, appear to have the highest affinity for nutrients (Stolte \& Riegman 1996) and are supposed to be favored by continuous, stringent nutrient limitation. Large species, on the other hand, are believed to benefit from a pulsed nutrient supply because of their higher uptake and storage potential (Turpin \& Harrison 1979, Stolte \& Riegman 1996).

In the Baltic Sea, the increased abundances of nuisance blooms of nitrogen-fixing cyanobacteria (Kahru et al. 2000) have often been attributed to eutrophication and reduced ratios of nitrogen $(\mathrm{N})$ to phosphorus (P), although N-limitation and the occurrence of cyanobacterial blooms are natural phenomena in the area (Bianchi et al. 2000).

The frequency of nutrient supply may be another important variable affecting cyanobacterial growth. Large filamentous cyanobacteria are superior in the storage of P (Larsson et al. 2001, Walve 2002) and have therefore been thought to benefit from a pulsed nutrient supply (Sommer 1985). Accordingly, mass occurrences of $\mathrm{N}_{2}$-fixing cyanobacteria in the Baltic Sea have sometimes been recorded after previous nutrient pulses originating from the upwelling of nutrient-rich bottom water (Grönlund et al. 1996, Kononen et al. 1996).

The increase in cyanobacterial blooms in the Baltic Sea is of particular concern as they are often toxic. The toxicity of the blooms is mainly due to 1 species, Nodularia spumigena Mertens, which produces a hepatotoxin called nodularin (Stal et al. 2003). Of the other bloom-forming cyanobacteria in the area, Baltic Aphanizomenon Morren is thought to be non-toxic (Stal et al. 2003), while the toxicity of Anabaena Bory, which is common in coastal waters, has not been established. Anabaena strains isolated from lakes, however, have been found to contain microcystins, another hepatotoxin (Rapala et al. 1997). The toxicity of cyanobacteria may be affected by nutrient concentrations as well as by nutrient ratios (Sivonen \& Jones 1999). In laboratory experiments, hepatotoxin production in Nodularia and Anabaena has been stimulated by high P concentrations and N-limitation (Lehtimäki et al. 1997, Rapala et al. 1997).

Phytoplankton responses to changes in the nutrient supply may be strongly influenced by the structure of the grazing community. Cottingham et al. (2004), for instance, showed that large zooplankton grazers such as Daphnia spp. may reduce the effect of nutrient pulses on the phytoplankton community in lakes. On the other hand, changes in phytoplankton abundance, species composition, chemical composition and palatability due to nutrient enrichment may affect zooplankton growth and reproduction (e.g. Sterner \& Hessen 1994, Jones \& Flynn 2005, Klein Breteler et al. 2005). Although the upward cascading effects of nutrient enrichment on the biomass of higher trophic levels are usually unclear (Micheli 1999), eutrophication has been reported to increase both total zooplankton biomass (Bays \& Crisman 1983, Pace 1986) and the relative proportion of microzooplankton over macrozooplankton (Bays \& Crisman 1983, Park \& Marshall 2000).

We conducted a mesocosm experiment in the northern Baltic Sea, in order to determine: (1) the effect of the N:P ratio and nutrient supply frequency on the phytoplankton community and possible interaction effects between the 2 variables; (2) the extent to which filamentous $\mathrm{N}_{2}$-fixing cyanobacteria are favored by a nutrient supply with a low N:P ratio and by a pulsed nutrient supply; (3) the effect of nutrient supply on cyanobacterial hepatotoxin production; (4) the possible upward cascading effects of nutrient enrichment on the zooplankton community.

\section{MATERIALS AND METHODS}

Study area. The study area was in the Archipelago Sea off the SW coast of Finland in the northern Baltic Sea. The Archipelago Sea is a shallow sea with a mean depth of only $23 \mathrm{~m}$. This non-tidal sea is characterized by a strong seasonality, with water temperatures reaching around $+20^{\circ} \mathrm{C}$ in summer and at least part of the sea being covered by ice in winter. The water is brackish, with a salinity of about 5 to $6 \mathrm{psu}$. The Archipelago Sea (and the whole Baltic Sea area) is severely affected by eutrophication. The external nutrient load 
mainly derives from diffuse loading, fish farming, aerial deposition, municipal wastewaters, and background loading from the Baltic proper and the Gulf of Finland. In the study area the summer mean concentrations of total nitrogen, total phosphorus and chlorophyll a (chl a) in the surface water are approximately $25 \mu \mathrm{M}, 0.65 \mu \mathrm{M}$, and $3 \mu \mathrm{g} \mathrm{l^{-1 }}$, respectively.

Experimental design. The $28 \mathrm{~d}$ mesocosm experiment was conducted close to Seili Island, in the middle of the Archipelago Sea $\left(60^{\circ} 15^{\prime} \mathrm{N}, 21^{\circ} 58^{\prime} \mathrm{E}\right)$ during late summer (from 8 August to 6 September 2001), a time when cyanobacteria are usually abundant in the area. The experiment was carried out in twelve 30 to $40 \mathrm{~m}^{3}$ cylindrical enclosures which were placed in a small bay 3 to $4 \mathrm{~m}$ in depth, where the euphotic zone reaches the bottom. The enclosures were made of double-layered transparent polyethylene and contained the whole water column, from surface to bottom; 8 of the enclosures had a plastic bottom and 4 had natural sediment as a bottom. The enclosures were of 2 types, since they had previously been used in another experiment studying sediment-water interactions (Suomela et al. 2005). The diameter of the enclosures was $3.6 \mathrm{~m}$ and the water depth in them varied from 3.1 to $3.9 \mathrm{~m}$. The upper edges of the enclosures was extended about $1 \mathrm{~m}$ above sea level to prevent waves from entering the enclosures. A detailed description of the site and of the mesocosm design and setup has been given by Suomela et al. (2005).

Two days prior to the start of the experiment, the water in the enclosures was changed by lowering the enclosure wall close to the bottom with the help of SCUBA divers. The water column was then carefully mixed before the enclosures were again raised. A nylon net (1 $\mathrm{mm}$ mesh size) on top of the enclosures prevented fishes and mysids from entering the enclosures during the water exchange.

The variation due to the difference between enclosure types (plastic-bottomed versus sediment-bottomed) was taken into consideration by using a randomized block experimental design (Sokal \& Rohlf 1995). The enclosures were grouped into 3 blocks, with the 4 sedimentbottomed enclosures forming 1 block and the 8 plastic-bottomed enclosures the other 2 blocks. The design was a $2 \times$ 2 factorial, with the interval between nutrient additions and the N:P ratio of the nutrient enrichment as treatment factors (Table 1). Each of the 4 treatments was replicated 3 times and allocated randomly to the enclosures within each block. Nutrients ( $\mathrm{N}$ and $\mathrm{P}$ ) were added either once a day (daily) or once a week (weekly) and in either an
$\mathrm{N}$-deficient ( $\mathrm{N}: \mathrm{P}=2.2 \mathrm{~mol}$ ) or an optimal Redfield ratio $(\mathrm{N}: \mathrm{P}=16 \mathrm{~mol}$ ) (Table 1$)$. The nutrient dose was 7 times higher in the weekly than in the daily enrichments, so that integrated over the whole experimental period the enclosures which received nutrients in the same N:P ratio also received the same total amounts of $\mathrm{N}$ and $\mathrm{P}$. All treatments received the same total amount of $\mathrm{P}$ but the addition of $\mathrm{N}$ varied depending on the $\mathrm{N}$ :P ratio of the treatment. Phosphorus was added as $\mathrm{KH}_{2} \mathrm{PO}_{4}$ and nitrogen as $\mathrm{NH}_{4} \mathrm{Cl}$ which, during summer, is the dominant form of inorganic nitrogen in the study area. All treatments were adjusted to the volume of the enclosures. The nutrients were added in the mornings (at 09:00 to 12:00 h) evenly in all 4 quarters of the enclosures using a plastic tube.

Sampling and analyses. Sampling was conducted in the afternoons 4 to $6 \mathrm{~h}$ after the nutrient additions. Subsamples were collected from 4 different quarters of the enclosures with a plastic tube that was lowered near to the bottom and then closed with a valve. The subsamples were pooled into a single sample.

Concentrations of chl $a_{\text {, ammonium }}\left(\mathrm{NH}_{4}{ }^{+}\right)$, phosphate $\left(\mathrm{PO}_{4}{ }^{3-}\right)$, and the sum of nitrite and nitrate $\left(\mathrm{NO}_{2}{ }^{-}\right.$ $+\mathrm{NO}_{3}{ }^{-}$) were analyzed at intervals of 2 to $3 \mathrm{~d}$, whereas total $\mathrm{N}$, total $\mathrm{P}$ and silica $\left(\mathrm{SiO}_{2}\right)$ were analyzed once a week. Nutrient and chl a analyses were performed using the standard methods described in Vuorio et al. (2005). Chl a samples were filtered onto Whatman GF/F glass-fiber filters which were stored frozen until analysis. The chl a filters were later thawed, extracted in ethanol and measured spectrophotometrically.

The phytoplankton community was examined at the beginning, middle and end of the experiment (Days 0, 14 , and 28, respectively). Samples were preserved with acid Lugol's solution (1.0\% final concentration) and counted with an inverted microscope using the Utermöhl technique (Utermöhl 1958). The heterocyst frequency of $\mathrm{N}_{2}$-fixing cyanobacteria was determined 5 times during the experiment by counting the number of heterocysts as a function of filament length. No separate samples were taken for picoplankton analyses;

Table 1. Experimental design. Treatments in the mesocosm experiment comprised additions of ammonium $\left(\mathrm{NH}_{4}{ }^{+}\right)$and phosphate $\left(\mathrm{PO}_{4}{ }^{3-}\right)$ in 2 different $\mathrm{N}: \mathrm{P}$ ratios ( $\mathrm{N}$-deficient, $\mathrm{N}$-def; Redfield ratio, Redf); added at 2 different intervals (daily, D; weekly, W)

\begin{tabular}{|llccrr|}
\hline Code & Treatment & $\begin{array}{c}\text { Addition } \\
\text { frequency }\end{array}$ & $\begin{array}{c}\text { Enrichment per addition } \\
\mathrm{NH}_{4}^{+} \\
\mu \mathrm{M}\end{array}$ & $\begin{array}{c}\mathrm{N}: \mathrm{P} \\
\mathrm{PO}_{4}{ }^{3-} \\
\mu \mathrm{M}\end{array}$ & ratio \\
\hline N-def D & N-deficient daily & $1 \mathrm{~d}$ & 0.12 & 0.05 & 2.2 \\
N-def W & N-deficient weekly & $7 \mathrm{~d}$ & 0.85 & 0.38 & 2.2 \\
Redf D & Redfield ratio daily & $1 \mathrm{~d}$ & 0.86 & 0.05 & 15.6 \\
Redf W & Redfield ratio weekly & $7 \mathrm{~d}$ & 6.00 & 0.38 & 15.6 \\
\hline
\end{tabular}


since picoplankton seemed to be abundant, however, a special effort was made to count them. Picoplankton was counted in the same way as phytoplankton, but in $2.5 \mathrm{ml}$ counting chambers, after $24 \mathrm{~h}$ sedimentation. Very dense samples were diluted. This is not an adequate method for counting picoplankton which, because of its small size does not all settle, and thus these results should be interpreted with caution. Phytoplankton cell biovolumes were obtained using appropriate volume formula according to Edler (1979). Carbon biomass was calculated from the biovolume by

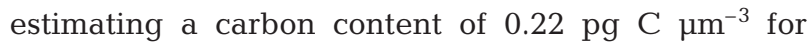
picoplankton (Li 1986), $0.13 \mathrm{pg} \mathrm{C} \mathrm{\mu m}^{-3}$ for thecate dinoflagellates and $0.11 \mathrm{pg} \mathrm{C} \mathrm{mm}^{-3}$ for all other phytoplankton cells (Mullin et al. 1966, HELCOM 1988).

Zooplankton samples were taken once a week (Days 0, 7, 14, 21 and 28) using a Limnos sampler from a depth of 0 to $2.5 \mathrm{~m}$. The samples (total $30 \mathrm{l}$ ) were concentrated on a $25 \mu \mathrm{m}$ mesh net and preserved in ice-cold $70 \%$ ethanol. Zooplankton were identified and enumerated with an inverted microscope and the biomasses were calculated according to average species-specific carbon biomass values (Pellikka \& Viljamaa 1998).

Water samples for hepatotoxin analyses were taken at the beginning, middle and end of the experiment (Days 0, 14, and 28) and stored frozen until analysis. The samples $(5 \mathrm{ml}$ ) were thawed at room temperature, sonicated in an ultrasonic bath (Sonorex Super 10P, Bandelin) for $60 \mathrm{~min}$, filtered through syringe filters (Whatman Puradisck, nominal pore size $0.2 \mu \mathrm{m}$ ), and kept in a refrigerator overnight. On the next day the samples, microcystin-LR standards $(0.1,0.4$ and $1.6 \mathrm{ppb}$ ) and negative controls were prepared and run in duplicate with an enzyme-linked immunosorbent assay (ELISA, EnviroGard Microcystins Plate Kit, Strategic Diagnostics). Hepatotoxin concentrations were measured with a spectrophotometer (Labsystems I EMS Reader MF) and analyzed with Windows-based microplate software Genesis II (Labsystems and Life Sciences International).

Statistical analyses. At the beginning of the experiment, we tested if the initial conditions differed between treatments using a 2-way ANOVA (SAS 1996). The complete experimental data were analyzed for the effects of nutrient ratio, frequency of nutrient enrichments and time with a mixed model for repeated measures (Littell et al. 1996, Proc MIXED, SAS 1996). Block was included in the model, but the statistical results on blocks are not shown in the tables or otherwise treated. To correct for the effects of small sample size, we used a model with Kenward-Roger estimates as the denominator of degrees of freedom (df) for the tests of fixed effects (Kenward \& Roger 1997). The assumption of normality was tested by evaluating the residuals with the Kolmogorov-Smirnov test. The data were $\log (x+1)$ or square root transformed if necessary to improve the fit. The mixed model for repeated measures was also used to determine if there were differences due to the enclosure types (sediment-bottomed versus plastic-bottomed).

\section{RESULTS}

\section{Initial conditions}

The initial conditions at the beginning of the experiment represented a typical late-summer situation with low concentrations of inorganic $\mathrm{N}$ and $\mathrm{P}$ and a low phytoplankton biomass $\left(41.7 \mu \mathrm{g} \mathrm{Cl}^{-1}\right)$. The mean concentrations of $\mathrm{NH}_{4}{ }^{+}, \mathrm{NO}_{2}{ }^{-}+\mathrm{NO}_{3}{ }^{-}$, and $\mathrm{PO}_{4}{ }^{3-}$ were $0.13,0.10$ and $0.07 \mu \mathrm{M}$, respectively, and the mean molar ratio of inorganic $\mathrm{N}$ to inorganic P (DIN:DIP) was 4.60.

The phytoplankton community was dominated by $\mathrm{N}_{2}$-fixing cyanobacteria, which made up 12 to $28 \%$ of the total biomass in the different treatments. Other abundant groups were Synechococcus-type picoplankton, cryptophytes (dominated by Plagioselmis prolonga Butcher and Teleaulax spp.), dinoflagellates (dominated by Dinophysis acuminata Claparède et Lachmann and Gymnodinium spp.), chrysophytes (dominated by Pseudopedinella spp.), centric diatoms and small unidentified flagellates. There were some differences in the initial phytoplankton abundances between the treatments, as the total phytoplankton biomass as well as the biomasses of picoplankton and chlorococcalean cyanobacteria were higher in the daily than in the weekly treatments $(p<0.05)$.

The initial mean zooplankton biomass was $10.9 \mu \mathrm{g} \mathrm{C}$ $\mathrm{l}^{-1}$. Rotifers (dominated by Keratella cochlearis Gosse, K. quadrata O. F. Müller and Synchaeta spp.) made up on average $49 \%$ and calanoid copepods (dominated by calanoid nauplii and Acartia spp.) $42 \%$ of the total zooplankton biomass. The cladoceran Bosmina longispina maritima P. E. Müller was abundant in some enclosures, whereas cyclopoid copepods occurred sporadically. There were no significant differences in the initial zooplankton biomasses among the treatments.

\section{Temperature and nutrient concentrations}

The water temperature in the enclosures varied between 18 and $19^{\circ} \mathrm{C}$ during the first $2 \mathrm{wk}$ of the experiment and then declined to around $17^{\circ} \mathrm{C}$. Cloudy and windy weather prevailed throughout the experiment, and most of the time the temperature was almost the same at the surface as at the bottom of the enclosures (3 $\mathrm{m}$ depth). 
As expected, the total $\mathrm{N}$ concentration increased most in the 2 treatments that received nutrients in a Redfield ratio (Fig. 1a, Table 2). The total $\mathrm{N}$ concentration also increased in the nitrogen-deficient (N-def) enrichment with daily addition, but remained close to
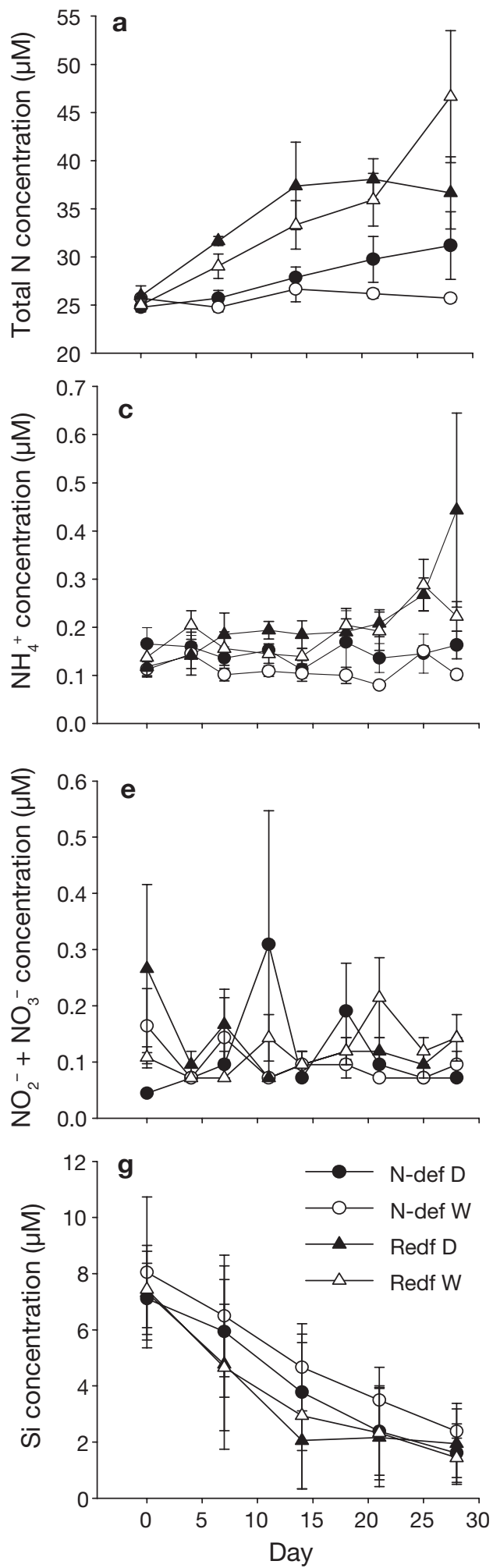

the initial values in the weekly $\mathrm{N}$-def treatment. Although all treatments received the same total amount of $\mathrm{P}$, the concentration of total $\mathrm{P}$ increased less in the weekly $\mathrm{N}$-def enrichment than in the other 3 treatments (Fig. 1b).
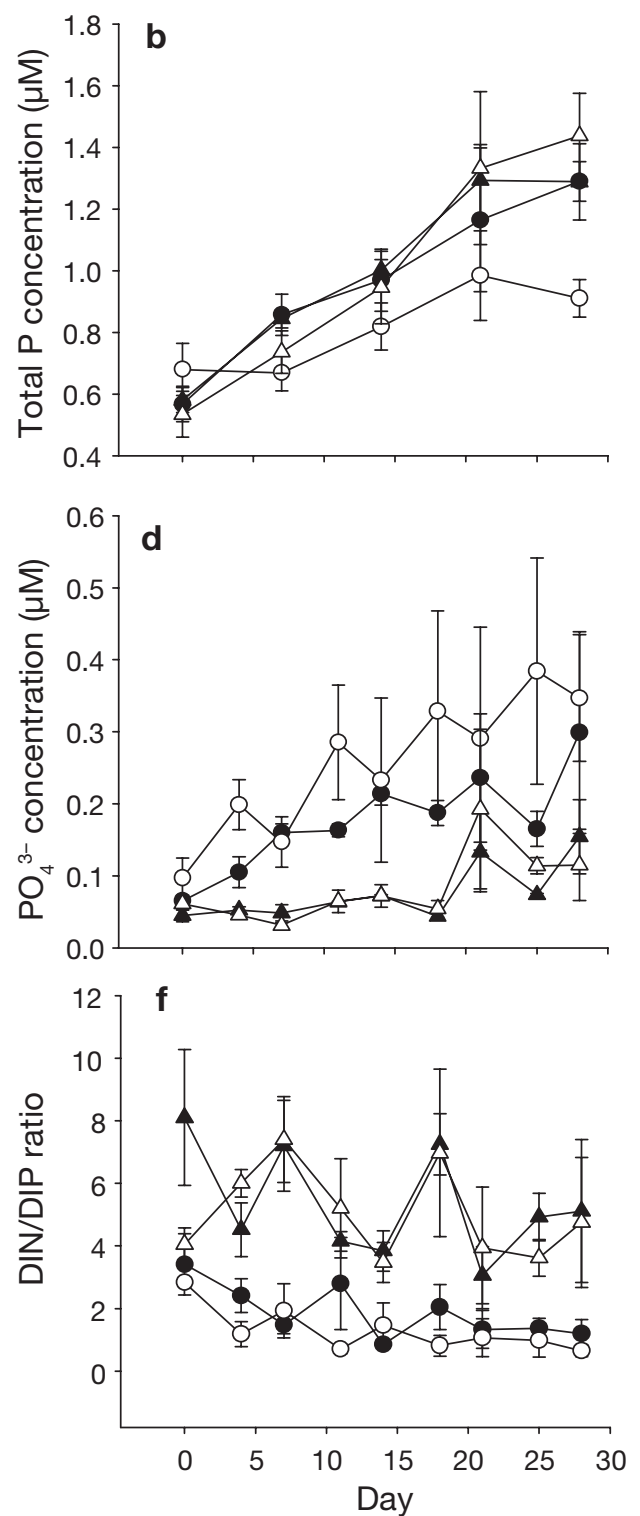

Fig. 1. Temporal variation in mean ( $\pm 1 \mathrm{SE})$ concentrations of (a) total nitrogen, (b) total phosphorus, (c) ammonium, (d) phosphate, (e) nitrite + nitrate, (f) inorganic $\mathrm{N}$ to $\mathrm{P}$ ratio, and (g) silicate in different enrichment treatments during the mesocosm experiment. For treatment codes see Table 1 
Table 2. Results of mixed model for repeated measures for nutrient concentrations in mesocosm experiment, showing p-values for effects of nutrient ratio (R), nutrient addition frequency (F), time, and their interaction effects. Boldface indicates statistically significant differences at $\mathrm{p} \leq 0.05$ after sequential Bonferroni correction (Rice 1989)

\begin{tabular}{|c|c|c|c|c|c|c|c|}
\hline & $\begin{array}{l}\text { Nutrient } \\
\text { ratio (R) }\end{array}$ & $\begin{array}{c}\text { Addition } \\
\text { frequency }(F)\end{array}$ & $\mathrm{R} \times \mathrm{F}$ & Time & Time $\times \mathrm{R}$ & Time $\times F$ & Time $\times \mathrm{R} \times \mathrm{F}$ \\
\hline Total N & $<0.0001$ & 0.025 & 0.11 & $<0.0001$ & $<0.0001$ & 0.17 & 0.0001 \\
\hline Total P & 0.0011 & 0.0066 & 0.026 & $<0.0001$ & 0.0099 & 0.23 & 0.023 \\
\hline $\mathrm{NH}_{4}^{+}$ & $<0.0001$ & 0.0033 & 0.39 & $<0.0001$ & 0.0001 & 0.0066 & 0.14 \\
\hline $\mathrm{NO}_{2}{ }^{-}+\mathrm{NO}_{3}{ }^{-}$ & 0.045 & 0.40 & 0.89 & 0.19 & 0.092 & 0.68 & 0.0002 \\
\hline $\mathrm{PO}_{4}{ }^{3-}$ & $<0.0001$ & 0.057 & 0.11 & $<0.0001$ & 0.0011 & 0.0027 & 0.035 \\
\hline DIN:DIP & $<0.0001$ & 0.040 & 0.51 & $<0.0001$ & 0.0018 & 0.15 & 0.029 \\
\hline $\mathrm{Si}$ & 0.0004 & 0.047 & 0.12 & $<0.0001$ & 0.16 & 0.85 & 0.94 \\
\hline
\end{tabular}

At the time when the water samples were taken, 4 to $6 \mathrm{~h}$ after the daily enrichment and $3 \mathrm{~d}$ after the weekly enrichments, the concentration of $\mathrm{NH}_{4}{ }^{+}$was under $0.3 \mu \mathrm{M}$ in all treatments during the first $3 \mathrm{wk}$ of the experiment (Fig. 1c). During the last week of the experiment the $\mathrm{NH}_{4}{ }^{+}$concentration increased in the Redfield (Redf) treatments. The concentration was also slightly higher in the daily than in the weekly enrichments (Fig. 1c, Table 2). The concentration of $\mathrm{PO}_{4}{ }^{3-}$ increased in all treatments, but most of all in the N-def treatments (Fig. 1d, Table 2). The concentration of $\mathrm{NO}_{2}{ }^{-}+\mathrm{NO}_{3}{ }^{-}$was low and did not differ among treatments (Fig. 1e, Table 2).

The molar ratio of inorganic $\mathrm{N}$ to $\mathrm{P}$ (DIN:DIP) was below 8 in all enclosures during the whole period, thus suggesting N-limitation in all treatments (Fig. 1f; see also Forsberg et al. 1978). As expected, the ratio was lower in the N-def than in the Redf treatments (Fig. 1f, Table 2). It is important to note, however, that for some time after the enrichment the $\mathrm{N}$ :P ratio in the Redf treatments must have been close to 16 , since the nutrients were added in that ratio and since the concentrations in the enclosures were low compared to the added amounts.

The concentration of Si decreased in all enclosures throughout the experiment, but the decrease was lower in the $\mathrm{N}$-def treatments than in the Redf treatments (Fig. 1g, Table 2).

\section{Phytoplankton biomass and composition}

The chl a concentration increased as a result of the nutrient enrichments (Fig. 2). It reached the highest values in the Redf treatments, in which it increased 3 - to 4 -fold during the experiment (Fig. 2, Table 3). The effect of addition frequency on the chl a concentration changed with time and between nutrient ratios (Table 3). After the first half of the experiment the chl a concentration was higher in the weekly than the daily
Redf enrichment, while in the N-def treatments the relationship between addition frequencies was the opposite (Fig. 2).

Like the chl a concentration, the microscopically determined total phytoplankton biomass also increased most in the Redf treatments (Fig. 3, Table 3). In the $\mathrm{N}$-def treatments the biomass increased more in the daily than in the weekly enrichment (Fig. 3).

Enrichments with the Redfield N:P ratio stimulated the growth of most phytoplankton groups: the chroococcalean cyanobacteria (Chroococcales), picoplankton, dinoflagellates (dominated by Dinophysis acuminata, Gymnodinium spp. and Heterocapsa triquetra Ehrenberg Stein), chlorophytes (especially Choricystis sp., Dictyosphaerium subsolitarium van Goor., Kirchneriella sp. and Oocystis spp.) and unidentified small flagellates (Fig. 3, Table 3). The biomasses of oscillatorialean cyanobacteria (Oscillatoriales) and chrysophytes (dominated by Pseudopedinella spp.) increased clearly only in the daily Redf enrichments (Fig. 3). The

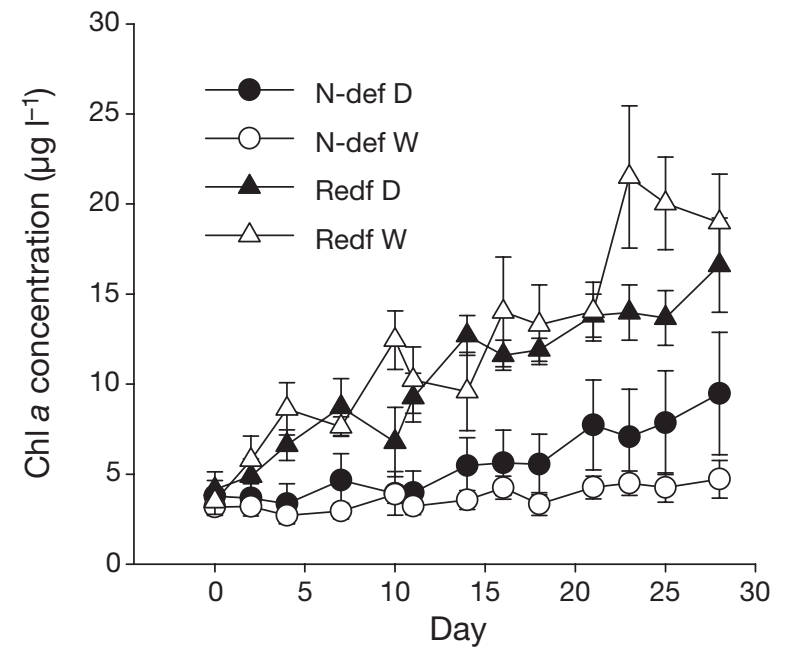

Fig. 2. Mean $( \pm 1 \mathrm{SE})$ concentration of $\mathrm{chl} a$ in different treatments during enrichment experiment. For treatment codes see Table 1 
Table 3. Results of mixed model for repeated measures for concentration of chl $a$, primary production, phytoplankton total biomass, biomasses of main phytoplankton groups, and dominant species in the nutrient enrichment experiment, showing p-values for effects of nutrient ratio (R), nutrient addition frequency $(\mathrm{F})$, time, and their interaction effects. Boldface indicates statistically significant differences at $\mathrm{p} \leq 0.05$; underlining indicates statistically significant differences at $\mathrm{p} \leq 0.1$ after sequential Bonferroni correction (Rice 1989)

\begin{tabular}{|c|c|c|c|c|c|c|c|}
\hline & $\begin{array}{l}\text { Nutrient } \\
\text { ratio (R) }\end{array}$ & $\begin{array}{c}\text { Addition } \\
\text { frequency (F) }\end{array}$ & $\mathrm{R} \times \mathrm{F}$ & Time & Time $\times \mathrm{R}$ & Time $\times F$ & Time $\times \mathrm{R} \times \mathrm{F}$ \\
\hline Chl a & $<0.0001$ & 0.99 & 0.014 & $<0.0001$ & $<0.0001$ & $<0.0001$ & $<0.0001$ \\
\hline Total phytoplankton & $<0.0001$ & 0.0032 & 0.039 & $<0.0001$ & $<0.0001$ & 0.13 & 0.19 \\
\hline Picoplankton & 0.0005 & 0.012 & 0.86 & 0.0002 & $<0.0001$ & 0.048 & 0.017 \\
\hline Chroococcales & 0.0008 & 0.014 & 0.31 & $<0.0001$ & 0.0003 & 0.48 & 0.12 \\
\hline Oscillatoriales & 0.0097 & 0.032 & 0.021 & $<0.0001$ & 0.029 & 0.097 & $\underline{0.0047}$ \\
\hline Nostocales & 0.66 & 0.0098 & 0.32 & $<0.0001$ & 0.47 & 0.0016 & 0.061 \\
\hline Cryptophytes & 0.13 & 0.19 & 0.084 & 0.012 & 0.0003 & 0.030 & 0.31 \\
\hline Dinoflagellates & $<0.0001$ & 0.12 & 0.41 & 0.17 & 0.0042 & 0.0027 & 0.51 \\
\hline Prymnesiophytes & 0.019 & 0.59 & 0.050 & $<0.0001$ & 0.016 & 0.68 & 0.69 \\
\hline Chrysophytes & 0.0003 & 0.0002 & 0.0012 & 0.64 & $<0.0001$ & 0.0047 & $<0.0001$ \\
\hline Centric diatoms & 0.0009 & 0.0053 & 0.050 & $<0.0001$ & $<0.0001$ & 0.0001 & 0.011 \\
\hline Pennate diatoms & 0.57 & 0.93 & 0.25 & 0.21 & 0.065 & 0.24 & 0.40 \\
\hline Prasinophytes & 0.61 & 0.14 & 0.69 & 0.72 & 0.048 & 0.10 & 0.59 \\
\hline Chlorophytes & $<0.0001$ & 0.22 & 0.96 & $<0.0001$ & $<0.0001$ & 0.0006 & 0.31 \\
\hline Unidentified flagellates & 0.0029 & 0.86 & 0.24 & 0.0002 & 0.019 & 0.45 & 0.98 \\
\hline Myrionecta rubra & 0.090 & 0.58 & 0.91 & 0.0005 & 0.18 & 0.70 & 0.012 \\
\hline
\end{tabular}

biomass of centric diatoms (dominated by Cyclotella spp. and Thalassiosira spp.) was significantly higher in the Redf than in the $\mathrm{N}$-def treatments at the middle of the experiment, but their biomass decreased in the daily Redf treatment at the end of the experiment. The N:P ratio had no statistically significant effect on the group of heterocystous $\mathrm{N}_{2}$-fixing cyanobacteria (Nostocales), although their biomass was highest in the daily N-def enrichment (Fig. 3, Table 3).

The effect of the nutrient addition frequency was most unambiguous in the group of heterocystous $\mathrm{N}_{2}$-fixing cyanobacteria (Nostocales) whose biomass increased more in the daily than in the weekly enrichments (Fig. 3, Table 3). In the N-def treatments, the biomass of centric diatoms was higher in the daily than in the weekly enrichment; in the Redf treatments, on the other hand, in the middle of the experiment the biomass was highest in the daily enrichment, while at the end of the experiment it was highest in the weekly enrichment. The effect of addition frequency on dinoflagellates changed with time (Table 3). In the middle of the experiment the biomass of dinoflagellates was higher in the weekly enrichments, but at the end it was higher in the daily enrichments (Fig. 3). Towards the end of the experiment, chlorophytes (dominated by Dictyosphaerium subsolitarium and Kirchneriella sp.) increased, particularly in the weekly Redf treatment, also resulting in an interaction effect between nutrient addition frequency and time (Fig. 3, Table 3).

There were no clear differences among the treatments in the biomass of cryptophytes, prymnesiophytes (Chrysochromulina spp.), prasinophytes, pen- nate diatoms and the autrophic ciliate Myrionecta rubra Lohmann (Fig. 3, Table 3).

\section{$\mathrm{N}_{2}$-fixing cyanobacteria, heterocysts and hepatotoxicity}

The biomass of heterocystous $\mathrm{N}_{2}$-fixing cyanobacteria (Nostocales) increased during the experiment. Of the $\mathrm{N}_{2}$-fixing genera, the biomass of Anabaena spp. at the end of the experiment was 3 to 5 times higher in the $\mathrm{N}$-def daily enrichment than in the other treatments (Fig. 4, Table 4). The biomass of Aphanizomenon sp. was highest in the same treatment, but the effects of the treatments on this species were statistically insignificant. The biomass of Nodularia spumigena was higher overall in the daily than in the weekly enrichments (Fig. 4, Table 4). This was mainly due to a bloom of $N$. spumigena (biomasses up to $35 \mu \mathrm{g} \mathrm{Cl}^{-1}$ ) in 2 enclosures receiving nutrients daily, but with different N:P ratios. There was an interaction effect of nutrient ratio and time due to the fact that the bloom occurred at the middle of the experiment in $1 \mathrm{~N}$-def enclosure and at the end of the experiment in 1 Redf enclosure (Fig. 4, Table 4).

The frequency of heterocysts in all $\mathrm{N}_{2}$-fixing genera was higher in the weekly than in the daily nutrient enrichments (Fig. 4, Table 4). In Anabaena spp. and Aphanizomenon sp. the frequency of heterocysts was also higher overall in the N-def than in the Redf treatments, although the nutrient ratio seemed to have no effect on Days 16 and 28 in Anabaena spp. (Fig. 4, 

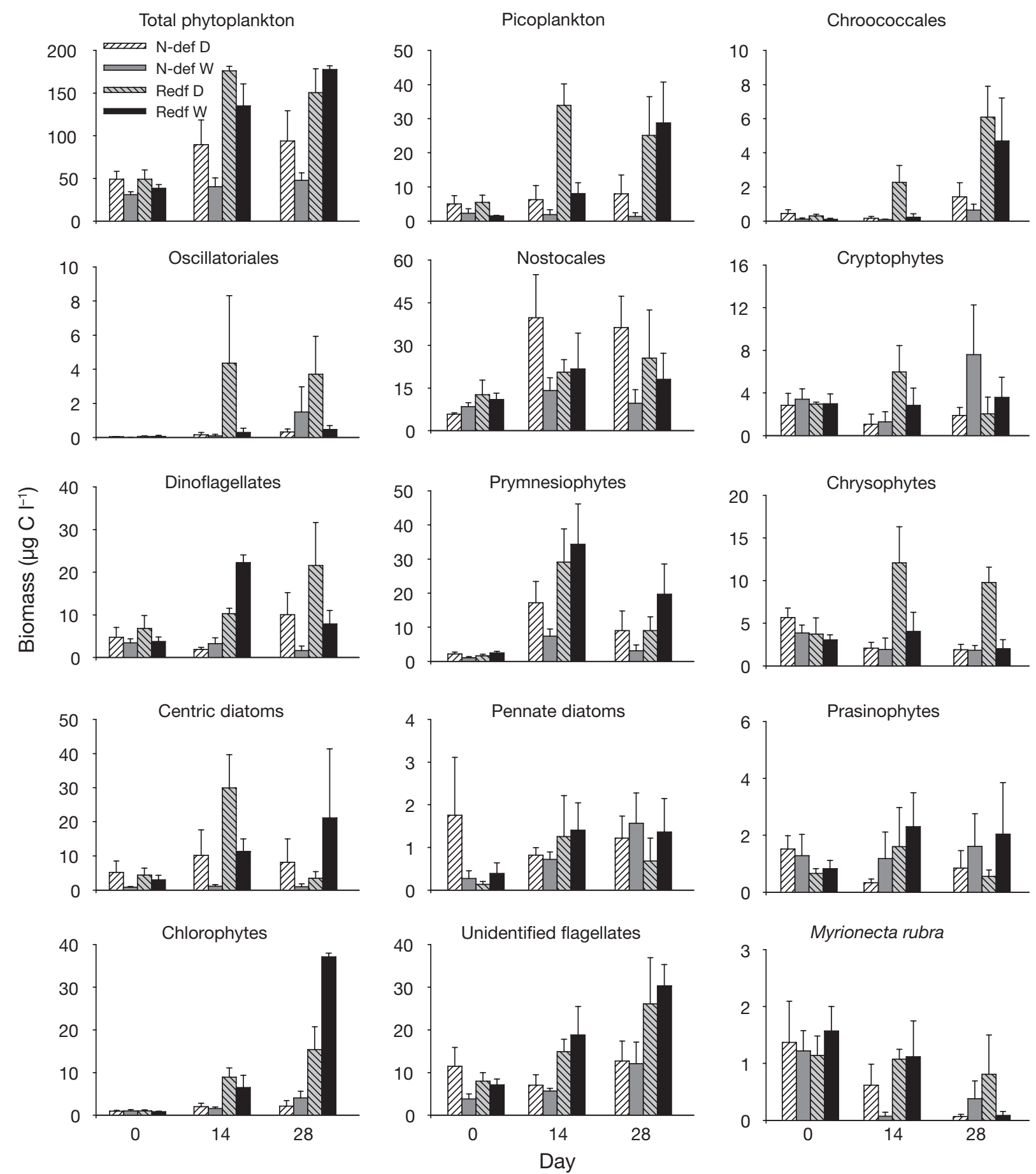

Fig. 3. Variation in mean $(+1 \mathrm{SE})$ carbon biomass of total phytoplankton and main phytoplankton taxa in different treatments at beginning of experiment and after 14 and $28 \mathrm{~d}$. For treatment codes see Table 1

Table 4). In Nodularia spumigena the frequency of heterocysts varied irregularly between the nutrient ratios (Fig. 4, Table 4).

The total concentration of hepatotoxins increased during the experiment, but there were no statistically significant responses to the treatments (Fig. 4). When the hepatotoxin concentration was compared to the biomass of Nodularia spumigena, the only certainly toxic species, the toxicity seemed to be higher in the $\mathrm{N}$-def weekly treatment than in the other treatments, but the difference was not quite statistically significant (Fig. 4, Table 4). 

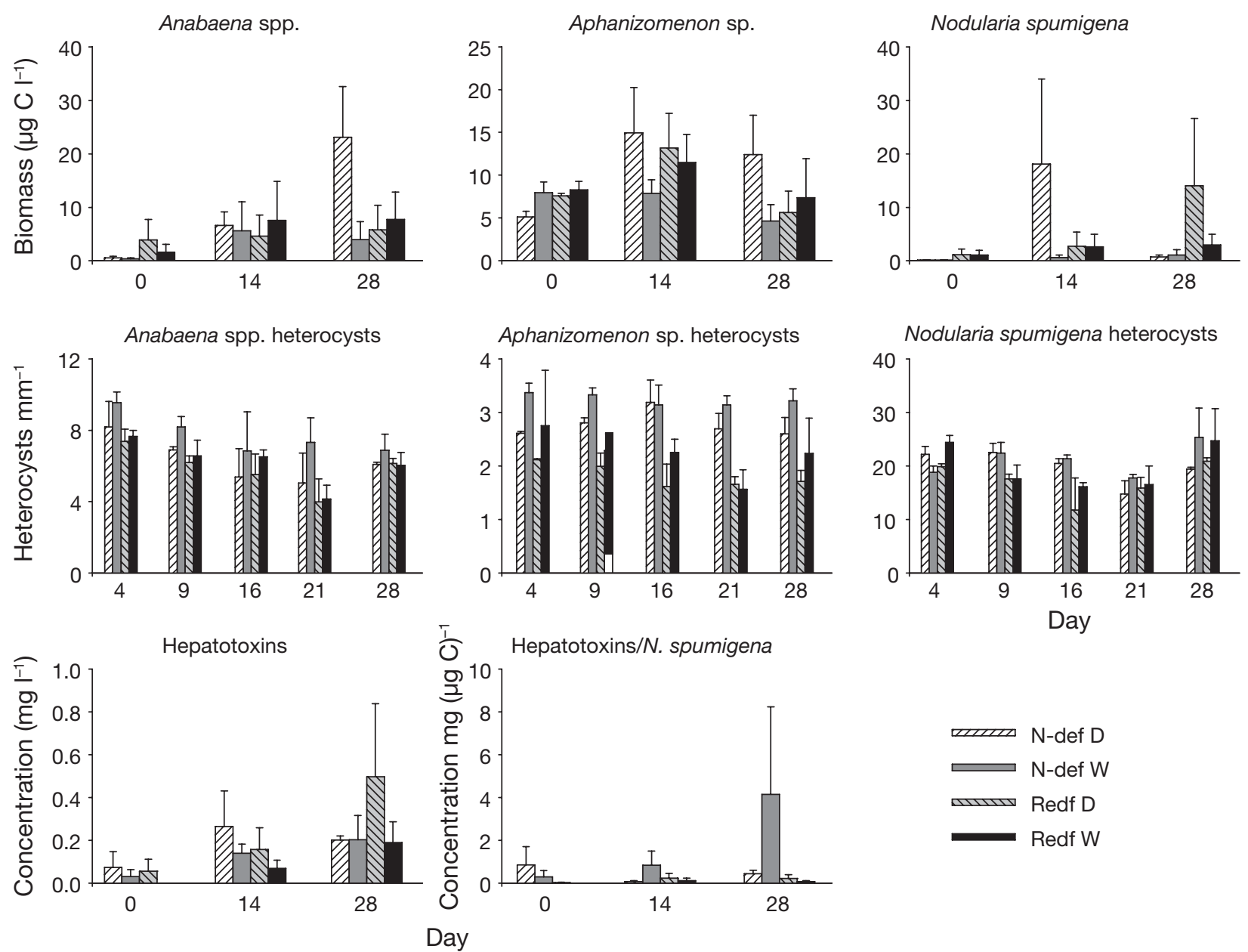

Fig. 4. Anabaena spp., Aphanizomenon sp. and Nodularia spumigena. Mean (+1 SE) carbon biomass heterocyst frequency, total hepatoxin concentration, and hepatoxin concentration divided by $N$. spumigena biomass in different treatments during enrichment experiment. For treatment codes see Table 1

Table 4. Results of mixed model for repeated measures for biomass of $\mathrm{N}_{2}$-fixing species, frequency of heterocysts and hepatotoxin concentration, showing p-values for effects of nutrient ratio (R), nutrient addition frequency (F), time, and their interaction effects. Boldface indicates statistically significant differences at $\mathrm{p} \leq 0.05$, underlining indicates significant differences at $\mathrm{p} \leq 0.1$ after sequential Bonferroni correction (Rice 1989)

\begin{tabular}{|lccccccc|}
\hline & $\begin{array}{c}\text { Nutrient } \\
\text { ratio (R) }\end{array}$ & $\begin{array}{c}\text { Addition } \\
\text { frequency }(\mathrm{F})\end{array}$ & $\mathrm{R} \times \mathrm{F}$ & Time & Time $\times \mathrm{R}$ & Time $\times \mathrm{F}$ Time $\times \mathrm{R} \times \mathrm{F}$ \\
\hline Anabaena spp. & 0.19 & $\underline{0.016}$ & $\mathbf{0 . 0 0 3 1}$ & $\mathbf{< 0 . 0 0 0 1}$ & $\underline{0.010}$ & $\mathbf{0 . 0 0 6 0}$ & $\mathbf{0 . 0 0 1 1}$ \\
Aphanizomenon sp. & 0.94 & 0.19 & 0.14 & $\mathbf{0 . 0 0 9 5}$ & 0.50 & 0.13 & 0.18 \\
Nodularia spumigena & 0.18 & $\underline{0.023}$ & 0.87 & $<\mathbf{0 . 0 0 0 1}$ & $\mathbf{0 . 0 0 0 3}$ & $\mathbf{0 . 0 0 1 4}$ & 0.062 \\
Anabaena spp. heterocysts & $\mathbf{0 . 0 0 0 9}$ & $\mathbf{0 . 0 0 2 6}$ & 0.036 & $\mathbf{0 . 0 0 0 1}$ & $<\mathbf{0 . 0 0 0 1}$ & 0.71 & 0.053 \\
Aphanizomenon sp. heterocysts & $\mathbf{0 . 0 0 0 1}$ & $\mathbf{< . 0 0 0 1}$ & 0.67 & 0.42 & 0.14 & 0.31 & 0.12 \\
N. spumigena heterocysts & 0.14 & $\mathbf{0 . 0 0 7 6}$ & 0.11 & $\mathbf{0 . 0 0 0 1}$ & $\mathbf{0 . 0 0 0 9}$ & 0.48 & 0.025 \\
Hepatotoxins & 0.84 & 0.037 & 0.30 & $\mathbf{0 . 0 0 2 2}$ & 0.13 & 0.67 & 0.27 \\
Hepatoxins/N. spumigena biomass & 0.034 & 0.54 & 0.25 & $\underline{0.0482}$ & 0.059 & 0.33 & 0.48 \\
\hline
\end{tabular}

\section{Zooplankton biomass and composition}

The total zooplankton biomass increased in all treatments during the last $2 \mathrm{wk}$ of the experiment (Fig. 5). In the N-def treatments the biomass was higher in the daily than in the weekly enrichments, especially during the later part of the experiment, while in the Redf treatments the relationship between the addition frequencies was the opposite, resulting in an interaction effect between nutrient ratio and addition frequency 


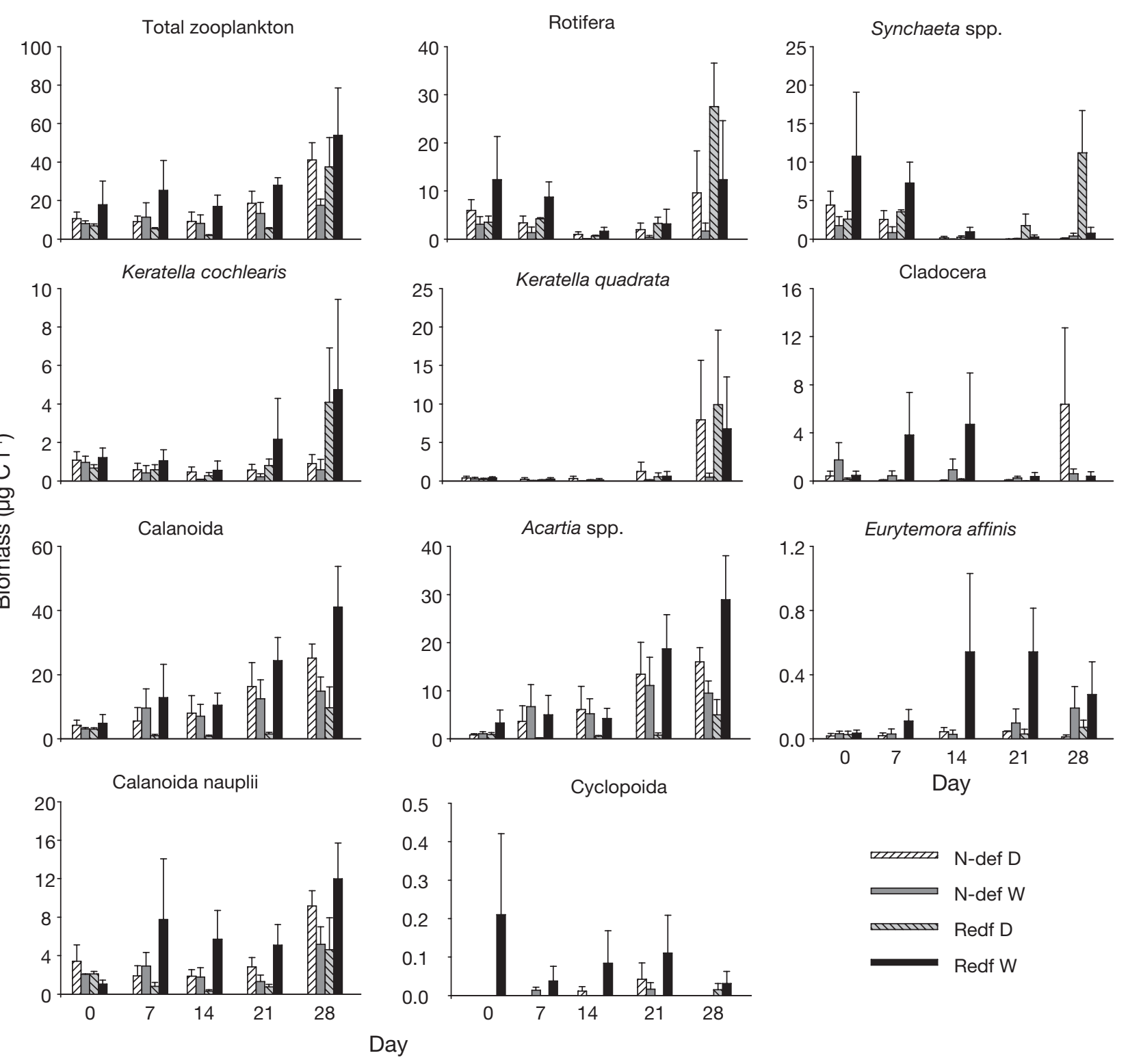

Fig. 5. Mean (+1 SE) carbon biomass of total zooplankton, zooplankton groups and main zooplankton species in different treatments on Days 0, 7, 14, 21 and 28 of mesocosm experiment. For treatment codes see Table 1

(Fig. 5, Table 5). The biomass increase in the Redf weekly enrichment was mainly due to the growth of calanoid copepods, dominated by Acartia spp. and calanoid nauplii. Eurytemora affinis Poppe also increased most in the Redf weekly treatment, although the species was not very abundant (Fig. 5, Table 5). The biomass of small rotifers (dominated by Synchaeta spp., Keratella cochlearis and K. quadrata) was higher in the Redf than in the N-def treatments (Fig. 5, Table 5). Towards the end of the experiment $K$. cochlearis increased in both Redf treatments, whereas Synchaeta spp. increased only in the daily Redf enrichment (Fig. 5). K. quadrata was not abundant until the last week of the experiment, but its biomass then increased in all other treatments except in the weekly $\mathrm{N}$-def treatment (Fig. 5). The abundances of cladocerans (mainly Bosmina longispina maritima and Podon intermedius Liljeborg) and cyclopoids were low and the groups were not statistically significantly affected by the treatments.

\section{Effects of enclosure type}

Due to the circumstances that some enclosures included the bottom sediment and others had a plastic bottom, the effect of the enclosure type was tested separately for all measured variables. The enclosure types 
Table 5. Results of mixed model for repeated measures for zooplankton total biomass and biomasses of main zooplankton groups, and dominant species, showing p-values for effects of nutrient ratio $(\mathrm{R})$, nutrient addition frequency $(\mathrm{F})$, time and their interaction effects. Boldface indicates statistically significant differences at $\mathrm{p} \leq 0.05$ after sequential Bonferroni correction (Rice 1989)

\begin{tabular}{|lcllllll|}
\hline & $\begin{array}{c}\text { Nutrient } \\
\text { ratio }(\mathrm{R})\end{array}$ & $\begin{array}{c}\text { Addition } \\
\text { frequency }(\mathrm{F})\end{array}$ & $\mathrm{R} \times \mathrm{F}$ & Time & Time $\times \mathrm{R}$ & Time $\times \mathrm{F}$ & Time $\times \mathrm{R} \times \mathrm{F}$ \\
\hline Total zooplankton & 0.59 & 0.16 & $\mathbf{0 . 0 0 1 5}$ & $\mathbf{< 0 . 0 0 0 1}$ & 0.51 & 0.023 & 0.13 \\
Rotifera & $\mathbf{0 . 0 0 1 1}$ & 0.020 & 0.21 & $\mathbf{< . 0 0 0 1}$ & 0.022 & $\mathbf{0 . 0 0 0 3}$ & $\mathbf{0 . 0 0 3 9}$ \\
Synchaeta spp. & $\mathbf{0 . 0 0 0 5}$ & 0.25 & 0.66 & $\mathbf{< . 0 0 0 1}$ & 0.12 & 0.24 & $\mathbf{0 . 0 0 0 4}$ \\
Keratella cochlearis & 0.088 & 0.64 & 0.36 & $\mathbf{< . 0 0 0 1}$ & 0.011 & 0.28 & 0.42 \\
Keratella quadrata & 0.29 & 0.025 & 0.051 & $\mathbf{< . 0 0 0 1}$ & 0.64 & 0.041 & 0.53 \\
Cladocera & 0.84 & 0.13 & 0.35 & 0.15 & 0.055 & 0.18 & 0.28 \\
Calanoida & 0.88 & $\mathbf{0 . 0 0 9 4}$ & $\mathbf{0 . 0 0 1 0}$ & $<\mathbf{0 . 0 0 0 1}$ & 0.55 & 0.19 & $\mathbf{0 . 0 0 7 7}$ \\
Acartia spp. & 0.71 & $\mathbf{0 . 0 0 9 8}$ & $\mathbf{0 . 0 0 1 8}$ & $\mathbf{< 0 . 0 0 0 1}$ & 0.16 & 0.14 & $\mathbf{0 . 0 0 2 3}$ \\
Eurytemora affinis & 0.059 & $\mathbf{0 . 0 0 4 9}$ & 0.051 & 0.10 & 0.37 & 0.24 & 0.076 \\
Calanoid nauplii & 0.27 & 0.023 & $\mathbf{0 . 0 0 0 4}$ & $<\mathbf{0 . 0 0 0 1}$ & 0.66 & 0.17 & 0.17 \\
Cyclopoida & 0.21 & 0.11 & 0.097 & 0.22 & 0.29 & 0.51 & 0.063 \\
\hline
\end{tabular}

differed only in the concentration of $\mathrm{Si}$ and in the biomass of diatoms, which were higher in the 4 sedimentbottomed than in the plastic-bottomed enclosures (data not shown, p < 0.05).

\section{DISCUSSION}

\section{Phytoplankton community responses}

Both the nutrient ratio and the interval between nutrient additions influenced the competitive outcome between phytoplankton species. Moreover, the effects of the nutrient ratio and the frequency of nutrient supply were not independent of each other, but also had combined impacts.

The higher increase in phytoplankton biomass in the Redf than in the N-def nutrient enrichments was expected, since the Archipelago Sea is known to be mainly N-limited (Kirkkala et al. 1998, Lagus et al. 2004, Vuorio et al. 2005). The biomass increase in the Redf treatments was due to the growth of chroococcalean cyanobacteria, picoplankton, oscillatorialean cyanobacteria, dinoflagellates, chrysophytes, centric diatoms, chlorophytes and unidentified small flagellates. The same groups have also previously been stimulated by nutrient additions in mesocosm experiments in the Baltic Sea (Kononen et al. 1993, Lagus et al. 2004, Vuorio et al. 2005).

In the $\mathrm{N}$-def treatments chl a concentration and total phytoplankton biomass were higher in the daily than in the weekly enrichment. The higher biomass in the daily enrichment was mainly due to a higher growth of $\mathrm{N}_{2}$-fixing cyanobacteria and centric diatoms. In the weekly N-def enrichment the total P concentration was lower than in the other treatments, suggesting that the plankton community was not able to utilize all added $\mathrm{P}$, which therefore was probably removed from the water column through precipitation and sedimentation.

When the nutrients were added in a Redfield ratio, during the later part of the experiment the weekly enrichment resulted in a higher chl a concentration than the daily enrichment. This difference between addition frequencies seemed mainly to be due to a high growth of chlorophytes towards the end of the experiment in the weekly enrichment. Since the initial biomass of chlorophytes was low, we suppose that only during the later part of the experiment had they built up a biomass high enough to exploit the high weekly nutrient pulses.

In the daily Redf treatment chrysophytes were favored during the whole experimental period whereas the biomasses of small centric diatoms and picoplankton were higher in the daily than in the weekly enrichment only in the middle of the experiment. One reason for these temporal changes may be that the groups were heavily grazed by rotifers, which increased in the daily Redf treatment during the later part of the experiment. As mentioned before, the method for picoplankton analyses may also have caused some error in the results. The diatoms may on the other hand, also have been limited by the availability of $\mathrm{Si}$, since the $\mathrm{Si}$ concentration decreased in the plastic-bottomed enclosures below the threshold concentration of $2 \mu \mathrm{M}$, which has been suggested to limit diatom growth (Egge \& Aksnes 1992, Brown et al. 2003). Si-limitation is also suggested by the fact that the biomass of diatoms was higher in the sediment-bottomed enclosures (in which the concentration of $\mathrm{Si}$ was higher) than in the plastic-bottomed enclosures.

In line with our results, Svensen et al. (2002) found in an $18 \mathrm{~d}$ mesocosm experiment in Norwegian marine waters that the chl a concentration was higher in treatments receiving nutrients (in a Redfield ratio) once or twice than in treatments receiving nutrients continu- 
ously. In their experiment the chlorophyll increase in the pulsed enrichments was due to the growth of the dinoflagellate Gyrodinium aureoleum, which was the only species that seemed to be favored by a pulsed nutrient supply (Svensen et al. 2002). They suggested that the higher biomass in the pulsed enrichments was due to a larger temporal mismatch between growth of phytoplankton and their zooplankton grazers. In contrast, Estrada et al. (2003) did not find any effect of nutrient addition frequency on the phytoplankton community in microcosm experiments in the Mediterranean. The initial nutrient concentrations in their study, however, were much higher than in our study; it is thus possible that the phytoplankton was not nutrient-limited at the beginning of their experiment. Moreover, the small chlorococcalean chlorophytes (especially Dictyosphaerium subsalsum and Kirchneriella sp.), which in the present experiment contributed much to the phytoplankton biomass in the weekly enrichments, were not present in the more marine waters studied by Svensen et al. (2002) and Estrada et al. (2003).

It has been suggested that pulsed nutrient supply should be advantageous for velocity and storage specialists (Sommer 1985, Grover 1991). The small chlorococcalean chlorophytes, which in this experiment benefited from weekly nutrient pulses, are known for their rapid growth responses to nutrient enrichment (Kononen et al. 1993, Moisander et al. 2003, Vuorio et al. 2005) and can therefore be categorized as velocity specialists. On the other hand, the biomass of cyanobacteria and chrysophytes was higher in the daily than in the weekly enrichments. The results are only partly in accordance with the results of Sommer (1985), who in a laboratory experiment with freshwater algae found that a pulsed $\mathrm{P}$ addition contributed to the advantage of chlorophytes but also to a storage specialist Aphanizomenon flos-aquae (cyanobacteria).

The reason that storage specialists, like large dinoflagellates (Dortch et al. 1984, Collos et al. 2004) and cyanobacteria (Larsson et al. 2001, Walve 2002), were not favored by the pulsed nutrient supply in the present study may be that the ability of phytoplankton to store $\mathrm{N}$ depends on the type of nitrogen source (Stolte et al. 1994, Stolte \& Riegman 1996). $\mathrm{NH}_{4}{ }^{+}$, which was used in this experiment, is a positive-charged or neutral $\left(\mathrm{NH}_{3}\right)$ molecule that may not be a suitable storage product, because it can easily diffuse across biological membranes (Stolte et al. 1994). $\mathrm{NO}_{2}{ }^{-}$is a negativecharged ion that does not diffuse so easily and can therefore be stored in higher concentrations in intracellular pools. Moreover, $\mathrm{NH}_{4}{ }^{+}$is most preferred by pico- and nanophytoplankton, whereas larger phytoplankton are more dependent on $\mathrm{NO}_{2}^{-}$(Stolte \& Riegman 1996). Since it is not always possible to distin- guish between autotrophic and heterotrophic flagellates with the Utermöhl technique, it is also possible that some of the dinoflagellates in the present study were mixotrophic or heterotrophic and thus not dependent on inorganic nutrients alone.

The grazing community may also have affected the outcome of the phytoplankton competition (Cottingham et al. 2004). An indication of this was seen in the dinoflagellates, which in the middle of the experiment were more abundant in the weekly than in the daily nutrient enrichments. The decrease of the dinoflagellates in the weekly enrichments during the second half of the study may have been due to selective grazing. Thin-walled dinoflagellates may have been preferred food for copepods, which increased in the weekly treatments during the later part of the experiment.

\section{Heterocystous $\mathrm{N}_{2}$-fixing cyanobacteria}

Since $\mathrm{N}_{2}$-fixing cyanobacteria are thought to be favored in N-limited conditions if enough P is available (Kononen et al. 1996, Kahru et al. 2000, Stal et al. 2003) and because of their capability to store nutrients (Sommer 1985, Larsson et al. 2001, Walve 2002), we had expected $\mathrm{N}_{2}$-fixing cyanobacteria to grow best in the $\mathrm{N}$ def weekly treatment. On the contrary, the total biomass of $\mathrm{N}_{2}$-fixing cyanobacteria was not statistically significantly affected by the nutrient ratio of the enrichments, but the biomass was higher in the daily than in the weekly enrichments. However, there were differences in the responses among the cyanobacterian genera.

Of the $\mathrm{N}_{2}$-fixing genera, Anabaena spp. clearly grew best in the N-def daily enrichment. The biomass of Aphanizomenon sp. also increased most in the N-def daily enrichment, but the treatment effects were not statistically significant. Nodularia spumigena was unaffected by the N:P ratio of the enrichments, but this species seemed to be favored by a daily nutrient supply.

These results are in line with those of previous studies in the same area, in which Anabaena spp. were stimulated by enrichments with a low N:P ratio whereas Aphanizomenon sp. and Nodularia spumigena were unaffected by the N:P ratio (Lagus et al. 2002, Vuorio et al. 2005). This is also mainly in accordance with the results of enrichment experiments in other parts of the Baltic Sea, in which the growth of filamentous, $\mathrm{N}_{2}$-fixing cyanobacteria dominated by N. spumigena and Aphanizomenon sp. was not affected by $\mathrm{N}$ and $\mathrm{P}$ additions (Kononen et al. 1993, Kuuppo et al. 2003), whereas Anabaena spp. were occasionally stimulated by P addition (Moisander et al. 2003).

The reason that the cyanobacteria did not respond more clearly to the nutrient ratio of the treatments may be that all the enclosures were $\mathrm{N}$-limited, as indicated 
by the low inorganic N:P ratio in all treatments. The accumulation of $\mathrm{PO}_{4}{ }^{3-}$ in both $\mathrm{N}$-def treatments indicated that the cyanobacteria were incapable of assimilating all the available $\mathrm{P}$, either because they were limited by some other growth-limiting factor or because they were controlled by some other variable. Nevertheless, since the biomass of Anabaena spp. was higher in the $\mathrm{N}$-def daily enrichment than in the other treatments, the availability of P may have limited the growth of this genus in the Redf treatments. The reason that Anabaena spp. grew better in the daily than in the weekly $\mathrm{N}$-def treatment may be that in the daily enrichment the genus was able to compete for inorganic N. This is supported by the fact that the cyanobacteria had more hetereocysts (indicating a higher $\mathrm{N}_{2}$-fixing rate: Lehtimäki et al. 1997), in the weekly than in the daily enrichment. Since $\mathrm{N}_{2}$-fixation is an energetically costly process, it is more advantageous for algae to grow on inorganic $\mathrm{N}$ than to fix molecular N (De Nobel et al. 1997).

Both Nodularia spumigena and Aphanizomenon sp. have been suggested to be able to form late-summer blooms in the Baltic Sea based on stored P from the early summer (Larsson et al. 2001, Walve 2002). Thus, at the beginning of the experiment, they may already have had sufficient $\mathrm{P}$ in storage for their growth and were therefore not P-limited nor stimulated by the pulsed nutrient supply. The positive response of $N$. spumigena to the daily enrichment was due to a bloom of this species in 2 enclosures with daily enrichment but with different nutrient ratios. The daily enrichment may have promoted the growth of $N$. spumigena; since, however, the other 4 enclosures with a daily enrichment showed no bloom formation, the factors that initiated the bloom could be more or less random or due to some variables that could not be controlled in the mesocosms. It is well known that the growth of cyanobacteria is enhanced by many other factors in addition to nutrient availability, such as low light, high water temperature, a stratified water column, intermediate salinities and the availability of trace elements (Stal et al. 2003). However, the factors that promote bloom formation are still unknown.

The concentration of hepatotoxin increased during the experiment, but was not statistically significantly affected by the nutrient enrichments. Although high $\mathrm{P}$ concentrations have stimulated cyanobacterian hepatotoxin production in laboratory studies (Lehtimäki et al. 1997, Rapala et al. 1997), the hepatotoxin concentration was also not affected by nutrient enrichments in a previous mesocosm experiment (Vuorio et al. 2005). Further study is needed before any firm conclusions can be drawn as to the effect of nutrient enrichments on the toxicity of cyanobacteria under natural conditions.

\section{Cascading effects on grazer community}

The total zooplankton biomass increased 3- to 4 -fold during the study. At the end of the experiment the biomass in the $\mathrm{N}$-def treatments was higher in the daily than in the weekly enrichment, while in the Redf treatments the result was the opposite. The fact that the zooplankton biomass responded to the treatments in the same way as the phytoplankton biomass suggests that zooplankton growth was food-limited. In contrast to our results, Svensen et al. (2002) did not find any responses of mesozooplankton to nutrient addition frequencies. While the phytoplankton biomass in their experiment was higher in the treatments with a lower nutrient addition frequency, the higher production resulted only in a higher sedimentation rate (Svensen et al. 2002).

The zooplankton biomass increase in the weekly Redf enrichment was mainly due to the growth of large zooplankton, especially calanoid copepods. Small rotifers, on the other hand, increased most in the daily Redf treatment. This difference in zooplankton species composition among treatments may have been due to a change in the taxonomic composition of the phytoplankton community. Picoplankton and small flagellates which increased in the daily enrichment probably enhanced growth of rotifers, whereas the weekly enrichment may have favored growth of larger algae, which may have been rapidly grazed by copepods. In addition to food quantity and prey species composition, the chemical composition of food may also affect zooplankton growth and reproduction (e.g. Sterner \& Hessen 1994, Jones \& Flynn 2005, Klein Breteler et al. 2005). Since zooplankton species differ in their demand and elemental composition of C, N and P (Andersen \& Hessen 1991, Sterner \& Hessen 1994, Elser et al. 2001), the N:P ratio of nutrient enrichments could also more directly affect zooplankton community structure. In the present experiment, the biomass of rotifers was higher in the Redf than in the N-def treatments, whereas the other zooplankton groups did not respond clearly to the N:P ratio of the enrichments. Thus, it is possible that the rotifers had a higher demand of $\mathrm{N}$ than the other zooplankton.

The results of the present study suggest that the effects of the nutrient inputs was cascading up the food chain, and affected the zooplankton community due to a change in both the quantity and quality of food. Previously it has been suggested that the linkages between nutrient load and upper trophic levels in marine systems are weak due to complexity within trophic levels and the advection of nutrients and organisms from open marine systems (Micheli 1999). It is possible that under natural conditions the zooplankton community is often so strongly controlled by 
grazing pressure from predators (which were absent from our enclosures) (Rudstam et al. 1994) or by other factors, such as hydrography (Viitasalo et al. 1995), that the role of food remains low.

\section{Consequences for water quality management}

It is well documented that enhanced nutrient inputs into coastal waters increase primary production and algal biomass (e.g. Hecky \& Kilham 1988, Smith et al. 2006). Eutrophication is one of the greatest problems of the Archipelago Sea as well as other parts of the Baltic Sea. Since the Archipelago Sea, like most other parts of the Baltic Sea, has been shown to be primarily N-limited (Kirkkala et al. 1998, Granéli et al.1990) a reduction of the N-load in the area would be likely to lead to a decrease in overall production. Some studies, however, have indicated that a reduction in the N-load may increase the biomass of $\mathrm{N}_{2}$-fixing cyanobacteria (Elmgren \& Larsson 2001a). It has even been suggested that any reduction in the N-load will be compensated by increased $\mathrm{N}_{2}$ fixation, making $\mathrm{N}$ reduction useless (Hellström 1996). In contrast, the results of this study suggest that in the Archipelago Sea, where the concentration of $\mathrm{P}$ is probably high enough to support growth of $\mathrm{N}_{2}$-fixing cyanobacteria, eutrophication can only be controlled and the intensity of cyanobacterial blooms reduced by management of both $\mathrm{N}$ and $\mathrm{P}$ discharges. A reduction in the N-load would decrease overall production and thereby also decrease the export of $\mathrm{O}_{2}$-consuming organic material to the bottom water. A lower sedimentation rate would, on the other hand, be likely to reduce the amount of anoxic bottom sediments which are one important source of $\mathrm{P}$ to the water column (Pitkänen et al. 2001). This is consistent with the general recommendations concerning both $\mathrm{N}$ and $\mathrm{P}$ management in the Baltic Sea (Granéli et al. 1990, Elmgren \& Larsson 2001b).

Based on our results, it seems that pulsed discharges of nutrients may be less harmful than a continuous nutrient supply, as the weekly nutrient enrichments resulted in a more favorable plankton community, with fewer cyanobacteria, more chlorophytes and larger zooplankton species. The frequency of nutrient supply needs to be taken into consideration in future enrichment studies and in estimating the effect of nutrient enrichments on plankton community structure. It is also important to note that the frequency of the nutrient supply and the nutrient ratio do not act independently as regulators of plankton communities, but have effects which can only be predicted from an understanding of their combined impact.
Acknowledgements. Funding for this research was provided by the Maj and Tor Nessling Foundation (research grants 2000198 and 2001092 to H.H. and A.L.), the Academy of Finland (research grants 47612 to H.H. and J.S., 52296 to J.M.L. and 201576 to K.S.), the Ella and Georg Ehnrooth Foundation (A.L.), Suomen Luonnonsuojelun Säätiö (A.L.) and the Jenny and Antti Wihuri Foundation (J.S.). We thank all the people who helped in the extensive field and laboratory work, V. Saarikari for analyzing the zooplankton samples, and K. Vuorio for helping with phytoplankton identification. We are also grateful to the Archipelago Research Institute at Seili for providing convenient working facilities. The laboratory at the Southwest Finland Regional Environment Centre is acknowledged for performing the water chemical analyses and for excellent cooperation. Thanks are also due to E. Valle for checking the language as well as to P. Kuuppo and 3 anonymous reviewers for constructive comments on the manuscript.

\section{LITERATURE CITED}

Andersen T, Hessen DO (1991) Carbon, nitrogen, and phosphorus content of freshwater zooplankton. Limnol Oceanogr 36:807-814

Bays JS, Crisman TL (1983) Zooplankton and trophic state relationships in Florida lakes. Can J Fish Aquat Sci 40: 1813-1819

Bianchi TS, Engelhaupt E, Westman P, Andrén T, Rolff C, Elmgren R (2000) Cyanobacterial blooms in the Baltic Sea: natural or human-induced? Limnol Oceanogr 45: 716-726

Brown L, Sanders R, Savidge G, Lucas C (2003) The uptake of silica during the spring bloom in the North East Atlantic Ocean. Limnol Oceanogr 48:1831-1845

Collos Y, Gagne C, Laabir M, Vaquer A, Cecchi P, Souchu P (2004) Nitrogenous nutrition of Alexandrium catenella (Dinophyceae) in cultures and in Thau lagoon, southern France. J Phycol 40:96-103

Cottingham KL, Glaholt S, Brown AC (2004) Zooplankton community structure affects how phytoplankton respond to nutrient pulses. Ecology 85:158-171

De Nobel WT, Snoep JL, Westerhoff HV, Mur LR (1997) Interaction of nitrogen fixation and phosphorus limitation in Aphanizomenon flos-aquae (Cyanophyceae). J Phycol 33: 794-799

Dortch Q, Clayton JR Jr, Thoresen SS, Ahmed SI (1984) Species differences in accumulation of nitrogen pools in phytoplankton. Mar Biol 81:237-250

Edler L (1979) Recommendations on methods for marine biological studies in the Baltic Sea. Phytoplankton and chlorophyll. Publ Balt Mar Biologists 5:1-38

Egge JK, Aksnes DL (1992) Silicate as regulating nutrient in phytoplankton competition. Mar Ecol Prog Ser 83:281-289

Elmgren R, Larsson U (2001a) Eutrophication in the Baltic Sea area: integrated coastal management issues. In: von Bodungen B, Turner RK (eds) Science and integrated coastal management. Dahlem University Press, Berlin, p 15-35

Elmgren R, Larsson U (2001b) Nitrogen and the Baltic Sea: managing nitrogen in relation to phosphorus. Sci World $\mathrm{J}$ 1:371-377

Elser JJ, Hayakawa H, Urabe J (2001) Nutrient limitation reduces food quality for zooplankton: Daphnia response to seston phosphorus enrichment. Ecology 82:898-903

Estrada M, Berdalet E, Vila M, Marrasé C (2003) Effects of pulsed nutrient enrichment on enclosed phytoplankton: 
ecophysiological and successional responses. Aquat Microb Ecol 32:61-71

Fenchel T (1988) Marine plankton food chains. Annu Rev Ecol Syst 19:19-38

Forsberg C, Ryding SO, Claesson A, Forsberg Å (1978) Water chemical analyses and/or algal assay? Sewage effluent and polluted lake water studies. Mitt Int Ver Theor Angew Limnol 21:352-363

Granéli E, Wallström K, Larsson U, Granéli W, Elmgren R (1990) Nutrient limitation of primary production in the Baltic Sea area. Ambio 19:142-151

Grover JP (1991) Resource competition in a variable environment: phytoplankton growing according to the variableinternal-stores model. Am Nat 138:811-835

Grönlund L, Kononen K, Lahdes E, Mäkelä K (1996) Community development and modes of phosphorus utilization in a late summer ecosystem in the central Gulf of Finland, the Baltic Sea. Hydrobiologia 331:97-108

Hecky RE, Kilham P (1988) Nutrient limitation of phytoplankton in freshwater and marine environments: a review of recent evidence on the effects of enrichment. Limnol Oceanogr 33:796-822

HELCOM (1988) Guidelines for the Baltic Monitoring Programme for the Third Stage. Part D. Biological determinands. Balt Sea Environ Proc 27D:1-161

Hellström T (1996) An empirical study of nitrogen dynamics in lakes. Water Environ Res 68:55-65

Jones RH, Flynn KJ (2005) Nutritional status and diet composition affect the value of diatoms as copepod prey. Science 307:1457-1459

Kahru M, Leppänen JM, Rud O, Savchuk OP (2000) Cyanobacteria blooms in the Gulf of Finland triggered by saltwater inflow into the Baltic Sea. Mar Ecol Prog Ser 207: 13-18

Kenward MG, Roger JH (1997) Small sample inference for fixed effects from restricted maximum likelihood. Biometrics 53:983-998

Kirkkala T, Helminen H, Erkkilä A (1998) Variability of nutrient limitation in the Archipelago Sea, SW Finland. Hydrobiologia 363:117-126

Klein Breteler WCM, Schogt N, Rampen S (2005) Effect of diatom nutrient limitation on copepod development: role of essential lipids. Mar Ecol Prog Ser 291:125-133

Kononen K, Lahdes EO, Grönlund L (1993) Physiological and community responses of summer plankton to nutrient manipulation in the Gulf of Finland (Baltic Sea) with special reference to phosphorus. Sarsia 78:243-253

Kononen K, Kuparinen J, Mäkelä K, Laanemets J, Pavelson J, Nõmmann S (1996) Initiation of cyanobacterial blooms in a frontal region at the entrance to the Gulf of Finland, Baltic Sea. Limnol Oceanogr 41:98-112

Kuuppo P, Samuelsson K, Lignell R, Seppälä J, Tamminen T, Andersson A (2003) Fate of increased production in latesummer plankton communities due to nutrient enrichment of the Baltic Proper. Aquat Microb Ecol 32:47-60

Lagus A, Silander M, Suomela J (2002) Influence of nutrient enrichments on cyanobacteria in the Archipelago Sea, Northern Baltic. Verh Int Ver Limnol 28:607-612

Lagus A, Suomela J, Weithoff G, Heikkilä K, Helminen H, Sipura J (2004) Species-specific differences in phytoplankton responses to $\mathrm{N}$ and $\mathrm{P}$ enrichments and the N:P ratio in the Archipelago Sea, northern Baltic Sea. J Plankton Res 26:779-798

Lapointe BE, Matzie WR (1996) Effects of stormwater nutrient discharges on eutrophication processes in nearshore waters of the Florida Keys. Estuaries 19:422-435

Larsson U, Hajdu S, Walve J, Elmgren R (2001) Baltic Sea nitrogen fixation estimated from the summer increase in upper mixed layer total nitrogen. Limnol Oceanogr 46: $811-820$

Lehtimäki J, Moisander P, Sivonen K, Kononen K (1997) Growth, nitrogen fixation, and nodularin production by two Baltic Sea cyanobacteria. Appl Environ Microbiol 63: $1647-1656$

Li WKW (1986) Experimental approaches to field measurements: methods and interpretation. Can Bull Fish Aquat Sci 214:251-286

Littell RC, Milliken GA, Stroup WW, Wolfinger RD (1996) SAS System for mixed models. SAS Institute, Cary, NC

Micheli F (1999) Eutrophication, fisheries, and consumerresource dynamics in marine pelagic ecosystems. Science 285:1396-1398

Moisander PH, Steppe TF, Hall NS, Kuparinen J, Paerl HW (2003) Variability in nitrogen and phosphorus limitation for Baltic Sea phytoplankton during nitrogen-fixing cyanobacterial blooms. Mar Ecol Prog Ser 262:81-95

Mullin MM, Sloan PR, Eppley RW (1966) Relationship between carbon content, cell volume, and area in phytoplankton. Limnol Oceanogr 11:307-311

Pace ML (1986) An empirical analysis of zooplankton community size structure across lake trophic gradients. Limnol Oceanogr 31:45-55

Park GS, Marshall HG (2000) Estuarine relationships between zooplankton community structure and trophic gradients. J Plankton Res 22:121-135

Pellikka K, Viljamaa H (1998) Zooplankton in the Helsinki sea area 1969-1996. Publ. No. 12/1998 City of Helsinki Environment Centre, Helsinki (in Finnish with English summary)

Pitkänen H, Lehtoranta J, Räike A (2001) Internal nutrient fluxes counteract decreases in external load: the case of the estuarial eastern Gulf of Finland, Baltic Sea. Ambio 30: 195-201

Rapala J, Sivonen K, Lyra C, Niemelä SI (1997) Variation of microcystins, cyanobacterial hepatotoxins, in Anabaena spp. as a function of growth stimuli. Appl Environ Microbiol 63:2206-2212

Rice WR (1989) Analysing tables of statistical tests. Evolution 43:223-225

Rudstam LG, Aneer G, Hildèn M (1994) Top-down control in the pelagic Baltic ecosystem. Dana 10:105-129

SAS (1996) SAS/STAT users' guide, Version 6.12. SAS Institute, Cary, NC

Sivonen K, Jones G (1999) Cyanobacterial toxins. In: Chorus I, Bartram $J$ (eds) Toxic cyanobacteria in water: a guide to their public health consequences, monitoring and management. WHO, E \& FN Spon, London, p 41-111

Smith VH, Joye SB, Howarth RW (2006) Eutrophication of freshwater and marine ecosystems Limnol Oceanogr 51: 351-355

Sokal RR, Rohlf FJ (1995) Biometry: the principles and practice of statistics in biological research, 3rd edn. WH Freeman \& Co, New York

Sommer U (1985) Comparison between steady state and nonsteady state competition: experiments with natural phytoplankton. Limnol Oceanogr 30:335-346

Sommer U (1989) The role of competition for resources in phytoplankton succession. In: Sommer U (ed) Plankton ecology: succession in plankton communities. SpringerVerlag, Berlin, p 57-106

Stal LJ, Albertano P, Bergman B, von Bröckel K, Gallon JR, Hayes PK, Sivonen K, Walsby AE (2003) BASIC: Baltic Sea cyanobacteria. An investigation of the structure and 
dynamics of water blooms of cyanobacteria in the Baltic Sea-responses to a changing environment. Contin Shelf Res 23:1695-1714

Sterner RW, Hessen DO (1994) Algal nutrient limitation and the nutrition of aquatic herbivores. Annu Rev Ecol Syst 25: $1-29$

Stolte W, Riegman R (1996) A model approach for size selective competition of marine phytoplankton for fluctuating nitrate and ammonium. J Phycol 32:732-740

Stolte W, McCollin T, Noordeloos AAM, Riegman R (1994) Effect of nitrogen source on the size distribution within marine phytoplankton populations. J Exp Mar Biol Ecol 184:83-97

Suomela J, Gran V, Helminen H, Lagus A, Lehtoranta J, Sipura S (2005) Effects of sediment and nutrient enrichment on water quality in the Archipelago Sea, northern Baltic: an enclosure experiment in shallow water. Estuar Coast Shelf Sci 65:337-350

Svensen C, Nejstgaard JC, Egge JK, Wassmann P (2002) Pulsing versus constant supply of nutrients $(\mathrm{N}, \mathrm{P}$ and $\mathrm{Si})$ : effect on phytoplankton, mesozooplankton and vertical flux of biogenic matter. Sci Mar 66:189-203

Editorial responsibility: Otto Kinne (Editor-in-Chief), Oldendorf/Luhe, Germany
Tilman D, Kilham SS, Kilham P (1982) Phytoplankton community ecology: the role of limiting nutrients. Annu Rev Ecol Syst 13:349-372

Turpin DH, Harrison PJ (1979) Limiting nutrient patchiness and its role in phytoplankton ecology. J Exp Mar Biol Ecol 39:151-166

Utermöhl H (1958) Zur Vervollkommnung der quantitativen Phytoplankton-Methodik. Mitt Int Ver Theor Angew Limnol 9:1-38

Vanni MJ (2002) Nutrient cycling by animals in freshwater ecosystems. Annu Rev Ecol Syst 33:341-370

Viitasalo M, Vuorinen I, Saesmaa S (1995) Mesozooplankton dynamics in the northern Baltic Sea: implications of variations in hydrography and climate. J Plankton Res 17 : 1857-1878

Vuorio K, Lagus A, Lehtimäki JM, Suomela J, Helminen H (2005) Phytoplankton community responses to nutrient and iron enrichment under different nitrogen to phosphorus ratios in the northern Baltic Sea. J Exp Mar Biol Ecol 322:39-52

Walve J (2002) Nutrient limitation and elemental ratios in Baltic Sea plankton. PhD thesis, Stockholm University

Submitted: September 2, 2005; Accepted: June 21, 2006

Proofs received from author(s): February 21, 2007 